\title{
Milton J. Rosenau (1869-1946) i strategia zarządzania lękiem w sferze zdrowia publicznego
}

\begin{abstract}
Milton J. Rosenau (1869-1946) and the strategy of fear management in the sphere of public health
\end{abstract}

\begin{abstract}
Summary
The American epidemiologist Milton J. Rosenau - one of the pioneers of public health - is the author of the concept of "conquest of fear", which stimulated the development of preventive medicine. However, this concept was in fact a kind of strategy of fear management and as such necessarily led to the gradual domination of preventive pro-health strategies by the permanent therapy strategies. The negative consequences of this strategy can be read in the main work of Rosenau, a preventive medicine textbook, and were presented in a literary form by the French writer Jules Romains.
\end{abstract}

Keywords: Milton J. Rosenau, public health, conquest of fear, fear management

Słowa kluczowe: Milton J. Rosenau, zdrowie publiczne, pokonanie strachu, zarządzanie strachem

Druga połowa XIX i pierwsza XX w. to czas rozwoju medycyny prewencyjnej. Znaczącą rolę odegrał $\mathrm{w}$ tym zakresie amerykański lekarz Milton J. Rosenau, którego badania i działalność organizacyjna wywarły decydujący wpływ na dziedzinę zdrowia publicznego, nadając jej wyraźnie prewencyjny charakter. Jednak jego koncepcja 
„pokonywania lęku”, będąca w istocie strategią zarządzania lękiem, z konieczności prowadziła do stopniowego zdominowania strategii prewencyjnych działań prozdrowotnych przez strategię permanentnej terapii, co z kolei zapoczątkowało proces pogłębiającej się medykalizacji społecznej.

\section{M.J. Rosenau - działalność i kariera medyczna}

Milton Joseph Rosenau urodził się 1 stycznia 1869 r. w Filadelfii; jego rodzice byli żydowskimi emigrantami z Niemiec ${ }^{1}$. Tytuł doktora nauk medycznych uzyskał w 1889 r. na Uniwersytecie Pensylwanii. Następnie podjął studia podyplomowe w Instytucie Higieny w Berlinie, Instytucie Pasteura w Paryżu i Instytucie Patologicznym w Wiedniu. Od 1890 do 1909 r. pracował w US Public Health Service, a w 1899 r. został mianowany dyrektorem Laboratorium Higienicznego w Waszyngtonie, którym kierował przez 10 lat. W 1909 r. został mianowany profesorem zwyczajnym medycyny prewencyjnej i higieny w Harvard Medical School; działalność dydaktyczną prowadził ponad ćwierć wieku. Wymagał, by każdy student medycyny przeprowadził badanie stanu zdrowotności w swej rodzinnej miejscowości i sporządził stosowny raport; praktyka ta przyjęła się $\mathrm{w}$ wielu amerykańskich szkołach medycznych. W 1913 r., wraz z inżynierami sanitarnymi - Williamem T. Sedgwickiem i George’em C. Whipple’em, założył Harvard-Massachusetts Institute of Technology School for Health Officers, pierwszą w USA stałą podyplomową szkołę zdrowia publicznego; w $1922 \mathrm{r}$. przekształciła się ona w Harvard School of Public Health, a Rosenau został w niej profesorem epidemiologii. W 1934 r. został prezydentem Society of American Bacteriologists. W 1935 r. odszedł z Harvardu na emeryturę, przeniósł się na Uniwersytet Północnej Karoliny i został tam dyrektorem Division of Public Health, a od 1940 r. do śmierci pełnił funkcję dziekana nowo powstałej School of Public Health. Dla uczczenia jego pamięci corocznie w Harvard School of Public Health wygłaszany jest Milton J. Rosenau Lecture. Zmarł 9 kwietnia 1946 r. w Chapel Hill w Północnej Karolinie.

Głównym obszarem jego zainteresowań była epidemiologia. Doświadczenie $w$ tej dziedzinie zdobywał jako kierownik izolacyjnego obozu na granicy Teksasu z Meksykiem, w którym zgromadzono migrantów zarażonych ospą, stwarzających poważne zagrożenie dla

${ }^{1}$ Informacje podajemy za: L.D. Felton, Milton Joseph Rosenau, „Journal of Bacteriology" 1947, nr 53(1), s. 1-3, oraz biogramem w Wikipedii: https://en.wikipedia.org/ wiki/Milton_J._Rosenau [dostęp: 17.03.2021]. 
całego pasa granicznego. Ta praktyka i badania laboratoryjne zaowocowały książką Disinfection and Disinfectants. A Practical Guide for Sanitariants, Health and Quarantine Officers, wydaną w 1902 r. ${ }^{2} \mathrm{Wy}-$ kazywał w niej konieczność stosowania środków dezynfekujących, antyseptycznych i bakteriobójczych w celu zapobiegania zakażeniom. Prowadził intensywne badania nad prątkami gruźlicy i nad antytoksynami błonicy i tężca. Ustalił stężenie glicerolu właściwe dla przechowywania szczepionki przeciw ospie, dzięki czemu zmniejszono zanieczyszczenie bakteryjne, zapobiegając $\mathrm{w}$ ten sposób infekcjom po szczepieniu. Podkreślał znaczenie czystości mleka, opowiadając się za jego pasteryzacją; rezultaty swych badań przedstawił w książce The Milk Question, wydanej w 1912 r. ${ }^{3}$ Do tej sprawy przywiązywał bardzo dużą wagę, a zachęcając do spożywania mleka ze względu na dużą wartość odżywczą, podkreślał znaczenie czystości udoju i przechowywania, ale także apelował, by nie pozbawiać niemowląt mleka matki - napisał na ten temat popularną broszurę All About Milk, wydaną w $1919 \mathrm{r}^{4}$

W 1913 r. Rosenau wydał swoje opus magnum: podręcznik Preventive Medicine and Hygiene, będący obszernym, liczącym 1074 strony, traktatem z zakresu medycyny zapobiegawczej i społecznej5. Okazał się on dziełem przełomowym, wytyczającym nowe drogi i nowe perspektywy dziedziny, którą obecnie określamy jako zdrowie publiczne, znacząco wpłynął też na promocję zachowań prozdrowotnych. Wydanie było wielokrotnie wznawiane - przez siedem pierwszych wydań (do $1951 \mathrm{r}$.) pod pierwotnym tytułem, a od wydania ósmego (w 1956 r.) pod zmienionym tytułem Preventive Medicine and Public Health; wydanie to zostało zaktualizowane i dopełnione tekstami 27 autorów ${ }^{6}$. Podręcznik

${ }^{2}$ Zob. M.J. Rosenau, Disinfection and Disinfectants. A Practical Guide for Sanitariants, Health and Quarantine Officers, P. Blakiston's Son \& Co, Philadelphia 1902.

${ }^{3}$ Zob. M.J. Rosenau, The Milk Question, Houghton Mifflin Company, Boston-New York 1912.

${ }^{4}$ Zob. M.J. Rosenau, All About Milk, Metropolitan Life Insurance Company, New York 1919.

${ }^{5}$ Zob. M.J. Rosenau, Preventive Medicine and Hygiene, D. Appleton and Company, New York-London 1913. Do książki włączone zostały trzy teksty innych autorów: Thomasa W. Salmona o chorobach psychicznych, George'a C. Whipple'a o ściekach i nieczystościach, Cressy L. Wilbura o statystykach długości życia.

${ }^{6}$ Redaktorem wydania był Kenneth F. Maxcy, emerytowany profesor epidemiologii na Uniwersytecie Johna Hopkinsa w Baltimore; zob. K.F. Maxcy (red.), Rosenau's Preventive Medicine and Public Health, Appleton-Century-Crofts, New York 1956. Tom liczył 1477 stron. M.J. Rosenau był redaktorem pierwszych sześciu wydań do 1935 r.; wydanie siódme zredagował w 1951 r. K.F. Maxcy. 
stał się pozycją klasyczną w swej dziedzinie ${ }^{7}$. Kolejne edycje były aktualizowane, rozszerzane i uzupełniane przez szereg autorów; dotychczas ukazało się prawie 20 edycji, wielkiej objętości, w których nie ma już tekstów Rosenaua, a jego nazwisko pojawia się jedynie w tytule kolejnych wydań ${ }^{8}$.

Rosenau był przede wszystkim uczonym-praktykiem, do swoich rezultatów dochodził przez badania eksperymentalne. Zakres tych badań był z jednej strony bardzo sprofilowany, skupiony na problemach epidemiologicznych i bakteriologicznych, $\mathrm{z}$ drugiej zaś w tym profilu bardzo szeroki: lepsze zaopatrzenie w mleko, witaminy w mleku, grypa i zapalenie płuc, polio, zatrucia pokarmowe, szczepionka przeciw ospie stanowiły zagadnienia dominujące. Jako badacz, autor, nauczyciel, także administrator, wywierał duży wpływ na swoich uczniów, współpracowników i korespondentów. W jednym z biogramów pośmiertnych napisano o nim: „Wszędzie osobom zajmującym się zdrowiem publicznym jego nazwisko było najbardziej znane spośród specjalistów $\mathrm{z}$ tej dziedziny. $\mathrm{W}$ jego salach wykładowych wykształcone zostało i zainspirowane więcej niż pokolenie studentów, a tysiącom innych był znany ze swojego wspaniałego podręcznika. Odczuwał satysfakcję, widząc, jakim powodzeniem cieszy się jego praca, i wiedząc, że zdobył zaufanie i szacunek autorytetów z zakresu zdrowia publicznego na całym świecie" 9 . Właśnie zdrowie publiczne tworzyło ramy i zarazem podstawę jego działań badawczych i organizacyjnych. We wstępie do swego głównego dzieła napisał: „Zamierzeniem niniejszej pracy jest objąć te dziedziny medycyny i związanych z nią nauk, które tworzą podstawę działania zdrowia publicznego" ${ }^{10}$.

\section{Pokonywanie lęku}

W 1910 r. Rosenau opublikował artykuł, w którym wyłożył swoje stanowisko w kwestii celów i metod zdrowia publicznego ${ }^{11}$. Posłużył

7 Zob. uwagi z okazji 50. rocznicy pierwszego wydania: F.B. Rogers, Fifty Years of Rosenau's Textbook (1913-1963), „American Journal of Public Health” 1963, nr 53(8), s. 1302-1304.

${ }^{8}$ Współczesne wydania ukazują się pod tytułem: Maxcy-Rosenau-Last Public Health and Preventive Medicine.

${ }^{9}$ Milton Joseph Rosenau, „Canadian Journal of Public Health / Revue Canadienne de Santé Publique" 1946, nr 37(8), s. 335.

10 „The work is planned to include those fields of the medical and related sciences which form the foundation of public health work"; M.J. Rosenau, Preventive Medicine..., op. cit., s. VII.

${ }^{11}$ Zob. M.J. Rosenau, The Uses Of Fear In Preventive Medicine, „Boston Medical and Surgical Journal” 1910, nr 162(10), s. 305-307. 
się w nim określeniem „pokonanie lęku” (conquest of fear), jednoznacznie wskazującym podstawowy i niezmienny cel działań w ramach zdrowia publicznego. Jego zdaniem na rozwój cywilizacji można patrzeć jako na ciągły proces pokonywania lęku przed różnego rodzaju niebezpieczeństwami i zagrożeniami ${ }^{12}$. Człowiek zawsze odczuwał lęk przed tym wszystkim, o czym sądził, że może mu zagrażać, a na co nie miał wpływu albo z powodu naturalnej niemożności skutecznego przeciwstawienia się zagrażającej sile, albo z powodu nieznajomości przyczyn powodujących zagrożenie. Przykładami pierwszego rodzaju lęków są m.in. obawy przed demonami czy przerażenie wzbudzone pojawieniem się komety, co miało zwiastować jakieś nieszczęście; przykładami drugiego rodzaju lęków są wszelkie obawy związane z możliwością zachorowania, w szczególności możliwością pojawienia się epidemii. W pierwszym przypadku rozwój wiedzy usuwa irracjonalne lęki i nie obawiamy się już duchów ciemności ani nie przeraża nas zaćmienie słońca; $w$ drugim przypadku zaś coraz lepsze poznawanie etiologii poszczególnych chorób, zwiększające możliwości zapobiegania i leczenia, zmniejsza poziom lęku. Te dwa rodzaje zadań - leczenie chorób i zapobieganie im - wyznaczają przestrzeń działań prozdrowotnych. Zadaniem medycyny jest jak najskuteczniejsze likwidowanie choroby, która zaatakowała jednostkę; zadaniem zdrowia publicznego jest jak najskuteczniejsze zapobieganie powstawaniu chorób.

$\mathrm{Z}$ racji swych zainteresowań badawczych, ale też z uwagi na wzrastające wówczas zagrożenie, Rosenau szczególną uwagę poświęcał kwestii zapobiegania chorobom zakaźnym, powodującym epidemie, takim jak cholera, tyfus czy żółta febra. Wskazywał, że podstawowe znaczenie ma poznanie i zrozumienie przyczyn wywołujących daną chorobę. Człowiek odczuwa strach przed chorobą, która zaatakowała jego organizm; ale człowiek lęka się już na samą myśl, że może zachorować. Wobec lęków przed czymś, czego rzeczywiste przyczyny są nam nieznane, pozostajemy bezradni; ale poznając rzeczywiste

\footnotetext{
12 Angielskie słowo fear używane jest w mowie potocznej zarówno w znaczeniu „strach”, jak i „lęk”. W psychologii rozróżnia się strach jako emocję wywołaną jakimś realnym zagrożeniem i lęk jako emocję wywołaną wyobrażonym lub przewidywanym niebezpieczeństwem; inaczej mówiąc, strach to lęk uprzedmiotowiony. Zob. A. Kępiński, Lęk, Wydawnictwo Literackie, Kraków 2002. Rosenau posługuje się słowem fear $\mathrm{w}$ jego rozumieniu potocznym, a więc dwuznacznym. Ponieważ jednak chodzi mu nie tylko i nie przede wszystkim o przeżywanie aktualnego, realnego zagrożenia, lecz głównie o emocję wywoływaną przez przewidywane wyobrażone niebezpieczeństwa, takie jak zagrożenie chorobą czy możliwość pojawienia się epidemii, dlatego wydaje się właściwe użycie polskiego słowa „lęk”. Jednak w niektórych kontekstach, gdy mówi on o konkretnych obawach, będziemy używać słowa „strach”.
} 
przyczyny tego, czego się lękamy, możemy podjąć skuteczną walkę. Rosenau wskazywał, jak bardzo zmniejszyła się zachorowalność na wiele chorób dzięki szczepieniom ochronnym, dzięki poprawie stanu sanitarnego i polepszaniu warunków życia. Tak więc to dzięki poznaniu przyczyn i uwarunkowań możliwe stało się podejmowanie skutecznych działań. Na przykład strach przed żółtą febrą powodował, że chorych poddawano kwarantannie, co było oczywiście działaniem nieskutecznym. Odkrycie, że wirusa powodującego chorobę przenoszą komary, umożliwiło walkę z nią poprzez likwidowanie owadów i zabezpieczanie się przed kontaktem z nimi. „Kiedy strach przed febrą zamieni się $\mathrm{w}$ strach przed komarami, w naszych portach morskich nie będzie już żółtej febry. Rozsądne warunki sanitarne zastąpią przestarzałą kwarantannę, pokonany zostanie jeszcze jeden lęk i dokonany zostanie wielki postęp" ${ }^{13}$.

Świadomość, że coraz lepiej radzić sobie będziemy, w miarę rozwoju wiedzy, z zagrożeniami zdrowotnymi, nie usunie oczywiście lęku przed chorobami, ale będzie to już inny rodzaj lęku. „Być może nawet ta pocieszająca myśl nie rozwieje obaw niektórych ludzi przed chorobami. Ale jeśli taki lęk nie został pokonany, to przynajmniej został on przeniesiony z nieświadomego lęku przed samą chorobą na rozsądny lęk przed jej przyczyną. Pierwszy jest szkodliwy, a drugi ma różne zastosowania" ${ }^{4}$. Bardzo szybko przekonano się, jak niezwykle skutecznym środkiem polepszania stanu zdrowotnego zarówno jednostek, jak i całych społeczności są działania profilaktyczne ${ }^{15}$. Rosenau wyprowadził stąd wniosek, że medycyna prewencyjna powinna posługiwać się naturalnym lękiem przed zachorowaniem, kierując ten lęk na odkrywanie rzeczywistych przyczyn chorób i skłaniając ludzi do zachowań minimalizujących ryzyko zadziałania tych przyczyn.

${ }^{13}$ „When the fear of fever is transferred to a fear of mosquitoes, there will be no more yellow fever in our seaports. Sensible sanitation will replace obsolete quarantine, one more fear will have been conquered, and a great advance will have been made"; M.J. Rosenau, The Uses Of Fear..., op. cit., s. 306.

${ }^{14}$ „Even this comforting thought will not, perhaps, dispel the dread some people have of disease. But if such fear has not been conquered, it has, at least, been transferred from an ignorant fear of the disease itself to a reasonable fear of its cause. The former is harmful and the latter has distinct uses"; ibidem, s. 307.

${ }^{15}$ Osiągnięcie dłuższej średniej życia w społecznościach zachodnich w XX w. tylko w niewielkiej mierze spowodowane zostało działaniami ściśle medycznymi, głównie zaś było rezultatem prewencji medycznej, w szczególności skutkiem polepszenia warunków sanitarnych, wzrostem higieny, odpowiednią dietą i ogólnie właściwszym trybem życia. Zob. J.B. McKinley, S.M. McKinley, R. Beaglehole, Trends in Death and Disease and the Contribution of Medical Measures, [w:] H.E. Freeman, S. Levine (red.), Handbook of Medical Sociology, Prentice Hall, Englewood Cliffs, N. J., 1988, s. 16. 
Lęk jest emocją bardzo pożyteczną, podobnie jak ból, który sygnalizuje chorobę lub uszkodzenie organizmu. Gdyby nie lęk przed zachorowaniem, ludzie, może nawet w swej większości, z wygodnictwa lub beztroski o wiele bardziej lekceważyliby zalecenia stosowania norm sanitarnych czy norm żywieniowych. Naturalny lęk jest więc sojusznikiem w walce z chorobami. „Ale ostateczne pokonanie nastąpi tylko wtedy, gdy ślepy lęk przed samą chorobą ustąpi oświeconej ocenie niebezpieczeństw. To jest właśnie ten lęk, którym posługuje się medycyna zapobiegawcza"16. Lęk przed chorobą staje się więc niejako narzędziem $\mathrm{w}$ rękach specjalistów $\mathrm{z}$ dziedziny zdrowia publicznego i problem $\mathrm{w}$ dużej mierze sprowadza się do umiejętności jak najsprawniejszego posługiwania się tym narzędziem. Tym samym jednak działania $\mathrm{w}$ zakresie zdrowia publicznego stają się strategią zarządzania lękiem.

\section{Od prewencji do eugeniki}

Rosenau nie chce wyeliminować lęku - wręcz przeciwnie, uważa, że jest on bardzo pożyteczny, ponieważ jeśli się czegoś nie boimy, to nie zabezpieczamy się przed tym. Inaczej mówiąc, podejmujemy działania zabezpieczające przed zachorowaniem, ponieważ lękamy się choroby. Tym samym lęk jest warunkiem koniecznym powstania i rozwoju dziedziny zdrowia publicznego jako systemu działań zabezpieczających przed pojawianiem się przyczyn wywołujących choroby. Jednak nie lęk nakierowany na chorobę, lecz na jej przyczynę. Taki lęk Rosenau nazywa oświeconą (enlightened) oceną niebezpieczeństw. Właśnie na tej „oświeconej” ocenie zagrożeń musi być oparta strategia działań $\mathrm{w}$ zakresie zdrowia publicznego, będąca $\mathrm{w}$ swej istocie strategią zarządzania lękiem.

Odpowiednie zarządzanie lękiem jest konieczne, ponieważ z jednej strony poczucie lęku jest warunkiem koniecznym zabezpieczania się przed niebezpieczeństwem, z drugiej strony jednak ludzie na ogół mają skłonność do lekceważenia zagrożeń. Zapobieganie zagrożeniom i zabezpieczanie się przed czynnikami chorobotwórczymi zależy zaś w dużej mierze od dobrej woli jednostek i ich gotowości, by stosować się do rad i zaleceń specjalistów z zakresu nauk medycznych i zdrowia publicznego. M.J. Rosenau w swym opus magnum tak o tym pisze:

16 „But the final conquest will come only when the blind fear of disease it-self has given place to an enlightened appreciation of the dangers. This, then, is the fear that preventive medicine uses"; M.J. Rosenau, The Uses Of Fear..., op. cit., s. 307. 
Świadomość, że większość infekcji przechodzi raczej bezpośrednio z człowieka na człowieka, przenosi wszystkie siły socjologii do medycyny zapobiegawczej. Zadanie medycyny zapobiegawczej jest przez to znacznie trudniejsze $\mathrm{z}$ uwagi na fakt, że większość infekcji zależy od kontroli samego człowieka. Bezlitośnie prowadzimy wojnę $\mathrm{z}$ owadami czy z zakażoną żywnością lub wodą. Innymi słowy, możemy w bardzo dużym stopniu arbitralnie kontrolować nasze otoczenie, ale kontrola samego człowieka wymaga zgody rządzonych. Dlatego łatwiej jest zwalczyć żółtą febrę, niż kontrolować dur brzuszny. Malarię łatwiej zwalczyć niż gruźlicę, wściekliznę niż grypę, włośnicę niż odrę. Bydło wydaje się milcząco wdzięczne, gdy jest chronione przez szczepienie przeciwko czarnej nóżce lub wąglikowi, ale człowiek buntuje się przeciwko jednemu z najlepszych specyfików - szczepieniu przeciwko ospie prawdziwej. Fakt, że człowiek jest głównym źródłem i rezerwuarem większości własnych zakażeń, znacznie zwiększa zakres i trudności pracy w zakresie zdrowia publicznego i często uzależnia zapobieganie chorobom od zmian społecznych. W tym sensie medycyna zapobiegawcza jest prawdziwą socjologią ${ }^{17}$.

Przez socjologię rozumie Rosenau niewątpliwie wszelką wiedzę o zachowaniach, reakcjach, oczekiwaniach itp. społeczności ludzkich wraz ze znajomością metod oddziaływania na nie w celu kształtowania pożądanych postaw i nawyków. Rosenau zdaje się zakładać, że im bardziej społeczeństwo jest „oświecone”, tym bardziej jest skłonne kierować się zaleceniami prozdrowotnymi. Działalność w zakresie zdrowia publicznego powinna więc być także działalnością wychowawczą.

W działalności wychowawczej zdrowia publicznego szczególnie ważną rolę odgrywają dwa czynniki, ściśle zresztą ze sobą powiązane: dostarczanie społeczeństwu informacji oraz edukacja prozdrowotna. Właśnie z uwagi na własności charakterologiczne i nawyki kulturowe jednostek samo informowanie będzie niewystarczające i musi temu

17 „The knowledge that most infections are spread rather directly from man to man brings in all the forces of sociology to that of preventive medicine. The task of preventive medicine is thereby rendered much more difficult from the fact that most infections depend upon the control of man himself. We ruthlessly wage war against insects or against infected food or water. In other words, we can arbitrarily control our environment to a very great extent, but the control of man himself requires the consent of the governed. Thus it is easier to stamp out yellow fever than to control typhoid fever. It is easier to suppress malaria than tuberculosis, rabies than influenza, trichinosis than measles. Cattle appear to be mutely thankful when protected by inoculation against blackleg or anthrax, but man rebels against one of the best of all specifics-vaccination against smallpox. The fact that man is the chief source and reservoir of most of his own infections adds greatly to the scope and difficulties of public health work and often makes the prevention of disease depend upon social changes. In this sense preventive medicine is the true sociology”. M.J. Rosenau, Preventive Medicine..., op. cit., s. 314. 
towarzyszyć kampania edukacyjna. Tylko pod warunkiem zaakceptowania przez przynajmniej znaczącą większość jednostek podawanych zaleceń sanitarnych, epidemiologicznych, żywieniowych itp. możliwa staje się współpraca między specjalistami z zakresu zdrowia publicznego, rządem i społeczeństwem.

Kampania edukacyjna powinna być prowadzona w tym samym czasie, gdy atakuje się chorobę. Ludzie są żywotnie zainteresowani informacją i pragną jej. Dostępne są dobrze sformułowane artykuły w gazetach, okólniki, broszury, wykłady, pokazy i inne typowe metody. Edukacja społeczności jest ważna dla uzyskania współpracy, ponieważ walka $\mathrm{z}$ epidemią bez aktywnego wsparcia ze strony ludności jest utrudniona. Wprawdzie podstawowym obowiązkiem odpowiedzialnego dowódcy jest uśmierzenie paniki i uspokojenie nieuzasadnionych obaw dotkniętej nią społeczności, jednak należy unikać przeciwnej skrajności. Zdrowy strach przed chorobą jest jednym z najlepszych instrumentów $\mathrm{w}$ arsenale sanitariusza. Postęp $\mathrm{w}$ walce $\mathrm{z}$ chorobami jest prawie beznadziejny, gdy ludzie w sposób obojętny podchodzą do zagrożeńn ${ }^{18}$.

Działania informacyjno-edukacyjne prowadzić zatem mają do utrwalenia stałej współpracy między społeczeństwem a tymi, którzy ponoszą odpowiedzialność za jego stan zdrowotny. Przy czym bardzo wyraźnie podkreślone zostaje, że odpowiedzialność za stan zdrowia społeczeństwa ponoszą nie tylko specjaliści medyczni wraz z rządem, ale także każda jednostka ludzka; to dlatego tak ważne jest, aby świadomość prozdrowotna jednostek była stale wzmacniana i pogłębiana.

M.J. Rosenau posuwa się jednak bardzo daleko w zaleceniach dotyczących poprawy stanu zdrowotności jednostek i społeczeństw. Wiadomo przecież, że pewne choroby, ułomności i nieprawidłowości w rozwoju osobniczym nie są powodowane zarazkami przenoszonymi na jednostkę przez niespełniające wymogów sanitarnych i higienicznych otoczenie lub przez inne zakażone jednostki, lecz ich przyczynami są czynniki wrodzone, które przenoszone zostają z rodziców na potomstwo. W dążeniu do podwyższania poziomu zdrowotności nie

18 „A campaign of education should be carried on at the same time that the disease is being attacked. The people are keenly alive and hungry for information. Well-worded articles in the newspapers, circulars, pamphlets, lectures, demonstrations, and the other usual methods are available. The education of the community is important in order to obtain cooperation, for it is a handicap to fight an epidemic without the active support of the people. While the first duty of the officer in charge is to allay panic and calm the unreasonable fears of the stricken community, the opposite extreme must be avoided. A healthy fear of the disease is one of the best instruments in the armamentarium of the sanitarian. It is almost hopeless to make progress against disease where the people supinely accept the conditions"; ibidem, s. 321 . 
wystarczą więc działania nakierowane na polepszanie warunków sanitarnych i na profilaktykę, czyli zapobieganie chorobom i ich wczesne wykrywanie, lecz należy także eliminować możliwość dziedziczenia chorób i ułomności. Zdrowie publiczne musi więc podejmować również działania o charakterze eugenicznym; eugenika wchodzi w zakres działań prozdrowotnych.

W swym głównym dziele amerykański epidemiolog zamieścił odrębny rozdział poświęcony dziedziczeniu i eugenice. Podkreśla w nim, że wprawdzie dziedziczności zawdzięczamy rozmaite zabezpieczenia przeciwko chorobom, ale niestety dziedziczone są również pewne nieuleczalne choroby, schorzenia i ułomności. Zdrowie publiczne nie może zatem nie podejmować stosownych działań także w tym zakresie.

Jednym z najlepszych zabezpieczeń, jakie mamy przed chorobami ciała i umysłu, jest to odziedziczone po naszych przodkach. Cały problem poprawy stanu ludzkiego, nie tylko z medycznego punktu widzenia, ale w szerszym socjologicznym ujęciu, opiera się na rozmnażaniu się jednostek zdrowych i eliminacji rozmnażania się jednostek niezdrowych. Nauka o eugenice (prawidłowej genezie) nabiera zatem szczególnego znaczenia $\mathrm{w}$ medycynie prewencyjnej. Lekarz, podobnie jak sanitariusz, jest bezsilny wobec wielu godnych ubolewania sytuacji, zarówno w odniesieniu do jednostki, jak i do całego społeczeństwa, które dziedziczymy po naszych przodkach i które dlatego są nieuleczalne - ale którym w dużej mierze można zapobiegać. Jesteśmy zainteresowani edukacją obecnego pokolenia w zakresie eugeniki, aby przyszłe pokolenia mogły mieć to najlepsze ze wszystkich praw nabywanych wraz $\mathrm{z}$ urodzeniem - dobrą ludzką protoplazmę ${ }^{19}$.

Rosenau wskazuje, że przychodzimy na świat z wrodzoną, odziedziczoną po rodzicach „protoplazmą”, czyli tym, co stanowi podłoże wszystkich zachodzących w naszym organizmie procesów życiowych i psychicznych. Dlatego działania eugeniczne uznane zostają za równie ważne i konieczne, jak wszelkie zabiegi prowadzące do zabezpieczania się przed chorobami. Medycyna prewencyjna, a tym samym zdro-

${ }^{19}$ „One of the best protections we have against diseases of body and mind is that which is inherited from our forebears. The whole problem of improving the human stock, not only from the medical view, but from the broader sociological standpoint, is based upon the breeding of the fit and elimination of the unfit. The science of eugenics (normal genesis), therefore, assumes especial importance in preventive medicine. The physician, as well as the sanitarian, stands impotent before many deplorable conditions both in the individual and in society at large, which are inherited from our ancestors and are, therefore, incurable-but largely preventable. We are interested in educating the present generation to the facts of eugenics so that future generations may have that best of all birthrights - good human protoplasm"; ibidem, s. 415. 
wie publiczne, faktycznie staje się eugeniką, ponieważ zapobieganie ma być realizowane nie tylko przez działania likwidujące możliwość wystąpienia zachorowań, lecz także przez działania uniemożliwiające jednostkom przekazywanie własnej chorobliwości, kalectwa i ułomności swemu potomstwu. Brak tego rodzaju działań skutkuje zwiększającą się liczbą „rodzin zdegenerowanych” (degenerate families), w których rodzą się kolejne pokolenia głuchych, ślepych, epileptyków, syfilityków, chorych psychicznie, niedorozwiniętych umysłowo itd. Rosenau wyprowadzał $\mathrm{z}$ tego wniosek, że należy wspierać rozmnażanie się jednostek zdrowych, a uniemożliwiać prokreację tym, które przekazywałyby niekorzystne cechy dziedziczne swoim dzieciom.

Rosenau wskazuje cztery metody zapobiegania dziedzicznemu przekazywaniu upośledzeń (defectives): (1) edukacja, (2) prawodawstwo, (3) rozdzielanie, (4) chirurgia. Edukację uznaje za metodę mało skuteczną, ponieważ większość osób upośledzonych nie jest zdolna zrozumieć przekazywanych treści. Jednak edukacja skierowana do „lepszej” części społeczności pomaga pośrednio, zwracając uwagę na sytuacje, którym $\mathrm{w}$ dużej mierze można zapobiec, oraz na potrzebę i skuteczne metody ich kontrolowania ${ }^{20}$. Dlatego sama edukacja nie wystarcza, musi jej towarzyszyć odpowiednie ustawodawstwo. Rosenau $\mathrm{z}$ aprobatą podaje przykłady siedmiu stanów USA, w których zaczęły obowiązywać ustawy zakazujące zawierania małżeństw osobom upośledzonym, np. epileptykom, debilom, niedorozwiniętym umysłowo, chorym psychicznie. Zwraca przy tym uwagę, że prawo z natury rzeczy jest, przynajmniej w tym przypadku, zawodnym środkiem zapobiegawczym, a dzieci urodzone $\mathrm{z}$ takich par poza małżeństwem są podwójnie poszkodowane: jako genetycznie upośledzone i jako wychowujące się poza rodziną ${ }^{21}$.

Idealną i humanitarną metodą eliminacji tych, którzy nie są w stanie mieć normalnego potomstwa, byłoby rozdzielanie (segregacja). Różnego rodzaju domy, szpitale i placówki dla osób upośledzonych zapobiegałyby $\mathrm{w}$ jakimś stopniu ich kontaktom $\mathrm{z}$ osobami nieupośledzonymi, jak też aktom seksualnym między nimi. Niestety jest to bardzo trudne w praktyce z powodu wielkości zadania i niemożności

${ }^{20}$ „Education directed toward the defective is a failure, for he is incapable of profiting by the lessons. The education of the better class of the community is indirectly helpful in calling attention to the situation as being largely preventable, and to the necessity and means for controlling it"; ibidem, s. 416.

${ }^{21}$ „Restrictive legislation is a praiseworthy effort, but has signally failed as a preventive measure, for the evident reason that it only adds illegitimacy to degeneracy, and thus the children enter on life's battle doubly handicapped"; ibidem. 
wyznaczenia granicy między „normalnością” a „nienormalnością”; na razie musimy więc być usatysfakcjonowani stosowaniem segregacji w przypadkach poddających się jednoznacznej ocenie ${ }^{22}$. Również w tym przypadku musimy pamiętać, że przecież osoby upośledzone mogą rozmnażać się przed, a także i po ich oddzieleniu od społeczeństwa.

Metoda chirurgiczna, czyli sterylizacja, posiada natomiast tę podstawową zaletę, że skutkiem jej zastosowania jest całkowite uniemożliwienie rozmnażania się; jest przy tym $\mathrm{z}$ medycznego punktu widzenia stosunkowo łatwa do wykonania i nie powoduje niepożądanych skutków ubocznych. Natomiast podstawowym problemem jest duża możliwość nadużyć i wyrządzania krzywdy. Nawet w całkowicie oczywistych przypadkach, takich jak obłąkanie, epilepsja czy wysoki stopień zdegenerowania, często danej osobie wyrządza się krzywdę jeszcze przed podjęciem decyzji o operacji ${ }^{23}$.

Poglądy amerykańskiego epidemiologa odczytujemy dzisiaj jako w większości nie do zaakceptowania ze względów etycznych, jak też jako przestarzałe i błędne z biologicznego punktu widzenia; oczywiście należy je interpretować w kontekście rozwoju ówczesnej wiedzy biomedycznej. Rozpoznanie, że pewne cechy są dziedziczone, prowadziło do przekonania, że wskazane jest, by cechy niepożądane likwidować, co skutkowałoby sukcesywnym polepszaniem stanu zdrowotnego kolejnych pokoleń. Ówczesny poziom wiedzy i technologii nie pozwalał na ingerencję w materiał genetyczny człowieka, natomiast można było promować kojarzenie par o korzystnych cechach i utrudniać, a nawet zabraniać, dobierania się parom o cechach niepożądanych. W wielu krajach prawnie zabroniono takim osobom zawierania małżeństw, a co więcej zaczęto wdrażać programy sterylizacji jednostek z wadami genetycznymi, kalekich, także ze środowisk patologicznych. Skrajny przykład stosowania eugeniki stanowią hitlerowskie Niemcy, gdzie po prawnych zakazach i przymusowych zabiegach medycznych przy-

\footnotetext{
${ }^{22}$ „Segregation would be an ideal and humane method of eliminating those who are incapable of having normal offspring. Further, the great difficulty is to detect the unfit individual who starts a strain of defectives and degenerates. It is evidently a hopeless task to know where to draw the line between the fit and the unfit, so that for the present we must be satisfied to enforce restrictive measures upon only those who are evident and well-marked examples"; ibidem, s. 416-417.

${ }^{23}$ „Sterilization is a measure which contains great potential possibilities for abuse and injustice. It probably will never receive general acceptance on account of the difficulty of determining upon whom the operation shall be done. Even in perfectly clear cases, such as the insane, the epileptic, or the high grade degenerate, the harm has often been done before the operation is decided upon"; ibidem, s. 418.
} 
stąpiono do fizycznej eksterminacji jednostek uznanych za „niegodne życia”. Wprawdzie po II wojnie światowej zrezygnowano z forsowania idei eugenicznych, jednak nie zaniechano całkowicie tego rodzaju praktyk i jeszcze $\mathrm{w}$ drugiej połowie XX $\mathrm{w}$. $\mathrm{w}$ prawodawstwie wielu krajów istniały ustawy pozwalające stosować działania eugeniczne, na przykład przymusową sterylizację, ze względów społecznych.

Postawy i tendencje eugeniczne bardzo szybko znalazły podatny grunt w Stanach Zjednoczonych Ameryki ${ }^{24}$. Idee eugeniczne propagowane były bardzo intensywnie, działało szereg towarzystw eugenicznych, a czołową postacią ruchu był Charles B. Davenport (18661944), profesor biologii na Uniwersytecie Harvarda, zdeklarowany zwolennik poprawiania jakości rasy ludzkiej drogą segregacji rasowej i prawnych zakazów rozmnażania się osobników „zdegenerowanych" ${ }^{25}$. Rosenau bardzo często powołuje się w swym dziele na opinie Davenporta i przytacza gromadzone przez niego dane statystyczne dotyczące środowisk patologii zdrowotnej i kryminalnej, mające służyć celom poprawiania cech ludzkich. Cytuje m.in. taką oto jego konstatację: „Zapomniano o fundamentalnym fakcie, że wszyscy ludzie są stworzeni jako określeni przez swoje protoplazmatyczne ukonstytuowanie i nierówni co do swoich sił i obowiązków"26. Można te słowa rozumieć jako obiektywne stwierdzenie faktu, że jednostki różnią się co do swych właściwości, skłonności i uzdolnień, ale można je też rozumieć w sensie wartościującym, jako uznanie, że pewni ludzie są $\mathrm{z}$ urodzenia gorsi biologicznie. Wyznawcy teorii eugenicznych opierali swe poglądy na wartościującym uznaniu naturalnej nierówności biologicznej jednostek ludzkich, z czego wyprowadzali wniosek, że tym „gorszym” należy uniemożliwiać przekazywanie cech niepożądanych swemu potomstwu. Rosenau przychyla się do tego stanowiska.

Poświęcamy tak wiele uwagi znaczeniu eugeniki w poglądach amerykańskiego epidemiologa na kwestię zdrowia publicznego, po-

${ }^{24}$ O początkach ruchu eugenicznego w USA zob. M. Lorenz, Proto-eugenic Thought and Breeding Utopias in the United States before 1870, „Bulletin of the German Historical Institute”, fall 2008, nr 43, s. 67-90. O dalszym rozwoju ruchu zob. M.H. Markfield, A More Perfect Union: Eugenics in America, „National Academy of Elder Law Attorneys Journal”, spring 2019, vol. 15, s. 17-37.

${ }^{25}$ Zob. omówienie jego sylwetki i działalności w: O. Riddle, Biographical Memoir of Charles Benedict Davenport 1866-1944, „National Academy of Sciences of the United States of America. Biographical Memoirs" 1947, vol. xxv, fourth memoir, s. 75-110. Zob. także Ch.E. Rosenberg, Charles Benedict Davenport and the Beginning of Human Genetics, „Bulletin of the History of Medicine” 1961, nr 35(3), s. 266-276.

${ }^{26}$ „It has forgotten the fundamental fact that all men are created bound by their protoplasmic make-up and unequal in their powers and responsibilities"; M.J. Rosenau, Preventive Medicine..., op. cit., s. 424. 
nieważ widoczna jest $\mathrm{w}$ nich bardzo istotna determinanta rozwoju tej dziedziny ${ }^{27}$. Rosenau podkreślał, że podstawowym celem zdrowia publicznego jest zwiększanie bezpieczeństwa zdrowotnego, co dokonywać się ma przez ogół działań prowadzących do stałego polepszania poziomu zdrowotności jednostek i populacji. Działania te sprowadzały się do wykrywania przyczyn problemów zdrowotnych i zapobiegania im bądź ich likwidowania. Rozwój ruchu eugenicznego ukazywał granice takiego podejścia - zdrowie publiczne zaczyna wyczerpywać swoje możliwości i dalszy jego rozwój zależeć będzie od możliwości usunięcia także tych zagrożeń zdrowotnych, które powodowane są przez wrodzone cechy organiczne i psychiczne jednostek. Późniejsze odkrycia w zakresie genetyki interpretowane będą przez wyznawców teorii eugenicznych jako potwierdzające zasadność takiego podejścia. A skoro dopuszcza się tak daleko idącą ingerencję $\mathrm{w}$ życie osobiste i społeczne, to tym łatwiej akceptowane będą kolejne nakazy i zakazy motywowane troską o stan zdrowotny jednostki i społeczeństwa.

Działalność naukowa, popularyzatorska i organizacyjna Rosenaua może zostać uznana za zamykającą ważny etap rozwoju dziedziny zdrowia publicznego, mianowicie etap prewencyjny. Wraz z rozwojem wiedzy biomedycznej specjaliści z zakresu zdrowia publicznego zaczęli coraz mocniej uświadamiać sobie, że pojmowana w aspekcie negatywnym, czyli zapobiegawczym, ich dziedzina doszła do kresu swych możliwości i jej dalszy rozwój zależeć będzie od rozszerzania zakresu pozytywnych działań zwiększających zdrowotność jednostkową i populacyjną. Prewencyjne działania $\mathrm{w}$ zakresie zdrowia publicznego prowadziły do coraz szerszego i pełniejszego regulowania życia społecznego przepisami prawnymi dotyczącymi norm sanitarnych, higieny osobistej, jakości pożywienia, stylu życia itd. Od momentu ustalenia się pewnego standardu prozdrowotnej organizacji społeczeństwa i zachowań jednostkowych dalsze podwyższanie poziomu zdrowotności jednostek i populacji mogło się dokonywać jedynie pod warunkiem skłonienia lub zmuszenia do właściwego postępowania na tyle dużej części społeczeństwa, że zachowania tej części, która z różnych powodów nie stosowała się do zaleceń prozdrowotnych, nie miały istotnego wpływu na ogólny poziom zdrowotności. Inaczej mówiąc, zdrowie publiczne zaczęło wchodzić w nowy etap rozwoju, charakteryzujący

${ }_{27}$ Zob. M. Nowacka, J. Kopania, Od medycyny prewencyjnej do programów eugenicznych. Droga rozwojowa zdrowia publicznego, „Kwartalnik Filozoficzny” 2016, XLIV, nr 1, s. 107-120. 
się coraz szerszą i pełniejszą medykalizacją społeczeństw w aspekcie przestrzegania społecznych i osobistych norm prozdrowotnych.

Rozwój eugeniki to pierwszy wyraźny sygnał uświadomienia sobie przez specjalistów z zakresu zdrowia publicznego, że konieczna staje się zmiana postawy prozdrowotnej z negatywnej, nakierowanej na usuwanie zagrożeń zdrowia, na postawę pozytywną, nakierowaną na medykalizację społeczeństw; celem eugeniki nie było w istocie usuwanie zagrożeń powodowanych przez gorszą ,protoplazmę”, lecz wzmacnianie zdrowotności populacji cieszącej się dobrą „protoplazmą”, to zaś było możliwe przez narzucanie jednostkom i całym społecznościom właściwej, czyli służącej wzmacnianiu zdrowotności, organizacji życia jednostkowego i społecznego, posuniętej tak daleko, że dopuszczającej także izolowanie jednostek „zagrażających” zdrowotności innych, a nawet (w reżimach totalitarnych) możliwość ich eksterminacji. Rok śmierci Miltona J. Rosenaua można uznać za symboliczny koniec prewencyjnego etapu rozwoju zdrowia publicznego. Nowy etap będzie się charakteryzował tym, że relatywnie w coraz mniejszym stopniu i zakresie działania prozdrowotne będą polegały na ochronie zdrowotnej przez usuwanie zagrożeń drogą polepszania warunków życia i wdrażania rozwiązań organizacyjnych skłaniających bądź zmuszających jednostki do zachowań prozdrowotnych, a w coraz większym zakresie na podejmowaniu działań legislacyjnych narzucających postawy i zachowania zwiększające naturalną zdrowotność jednostek i populacji i zapobiegające aktualizowaniu się potencjalnych zagrożeń chorobowych.

\section{Od prewencji do medykalizacji}

Proces medykalizacji społeczeństwa zaczął się jeszcze za życia Rosenaua i bardzo szybko się dynamizował. W wieku XIX dokonało się - jak to określił jeden z pionierów zdrowia publicznego - „wielkie przebudzenie sanitarne" (the great sanitary awakening) ${ }^{28}$, natomiast $\mathrm{w}$ następnym stuleciu rozpoczął się proces wielkiej medykalizacji społecznej. Coraz szerzej i coraz intensywniej propaguje się zalecenia i nakazy medyczne mające skutkować polepszaniem zdrowotności, coraz częściej też zostają one wprowadzane w życie drogą regulacji prawnych. Rosenau jest jedną ze sztandarowych postaci szczytowej

${ }^{28}$ Zob. Ch.-E. A. Winslow, The Conquest of Epidemic Disease. A Chapter in the History of Ideas, The University of Wisconsin Press, Wisconsin 1980, s. 236 i n. Pierwsze wydanie tej klasycznej monografii ukazało się w $1923 \mathrm{r}$. O podejmowanych w XIX w. działaniach administracyjnych decydujących dla rozwoju zdrowia publicznego zob. M. Nowacka, Od policji medycznej do zdrowia publicznego. Rozwój administracji zdrowotnej w XIX wieku, w druku. 
fazy owego „przebudzenia sanitarnego”. Coraz lepsze rozumienie, jak decydującym czynnikiem w zapobieganiu chorobom i epidemiom są szeroko pojęte warunki sanitarne, stymulowało rozwój medycyny prewencyjnej, a Rosenau odegrał szczególnie ważną rolę w tworzeniu naukowych i organizacyjnych podstaw tego rozwoju. Nie mógł więc nie zdawać sobie sprawy z prostej zależności między skutecznością zapobiegania zagrożeniom zdrowotnym, a sprawnością organizacyjną. Postulowana przezeń strategia zarządzania lękiem - choć nigdy nie sformułował jej zasad i metod ani nie opisał środków - miała pomagać w sprawnej organizacji życia społecznego służącej celom prozdrowotnym. A zaaprobowanie przezeń zasad eugeniki pozwala domniemywać, że gotów był akceptować bardzo daleko posuniętą ingerencję w życie jednostki i społeczności, jeśli miałaby ona zwiększać poziom zdrowotności. W ostatnim ćwierćwieczu jego życia było już wyraźnie widoczne, że zdrowie publiczne (i medycyna prewencyjna jako jego część) dąży do jak najsilniejszego podporządkowania sobie życia społecznego, do takiego organizowania społeczeństwa, aby nie tylko jak najskuteczniej chronić zdrowie, lecz także jak najskuteczniej zwiększać poziom zdrowotności ${ }^{29}$. Inaczej mówiąc, działania w zakresie zdrowia publicznego rozszerzały i pogłębiały medykalizację społeczeństw. Rosenau nie komentował tych procesów; być może ich nie dostrzegał, jednak bardziej prawdopodobne jest, że przyjmował je jako oczywiste.

W pierwszej połowie XX w. medykalizacja społeczna dokonywała się głównie przez akcje uświadamiające podejmowane przez środowiska lekarskie, co jest tym bardziej skuteczne, im bardziej zwiększa się w krajach zamożnych dostęp szerszych kręgów ludności do świadczeń medycznych; w drugiej połowie stulecia akcjom uświadamiającym towarzyszyć będą coraz szersze regulacje prawne zasad organizacyjnych w przestrzeni zdrowia publicznego. Zwiększa się przekonanie, że każdy jest potencjalnym pacjentem, a względnie dobre samopoczucie zdrowotne nie powinno nikogo odwodzić od w miarę regularnych kontrolnych wizyt u lekarza. To przekonanie może być określane za

${ }^{29}$ Wiązało się to ze zrozumieniem, że nie tylko urządzenia sanitarne, lecz także, a nawet przede wszystkim, każda jednostka ludzka jest źródłem transmisji chorób. „In the early twentieth century, the role of the state and local public health departments expanded greatly. Although disease control was based on bacteriology, it became increasingly clear that individual persons were more often the source of disease transmission than things"; The Future of Public Health, Committee for the Study of the Future of Public Health; Division of Health Care Services, National Academy Press, Washington 1988, s. 65. 
M.J. Rosenauem jako oświecona ocena niebezpieczeństw. Warunkiem koniecznym dokonania takiej „oświeconej” oceny niebezpieczeństwa w odniesieniu do własnego poziomu zdrowotności jest oczywiście żywienie przez jednostkę lęku przed możliwością zachorowania; tym samym jednak strategia prozdrowotnego organizowania życia społecznego musi stać się strategią zarządzania lękiem. Zdrowie publiczne przechodzi w swym rozwoju od fazy sanitarnej, przez fazę prewencyjną do fazy terapeutycznej, aby w drugiej połowie XX w., w rezultacie zwiększania presji prozdrowotnej na jednostkę i społeczeństwo, wejść w nową fazę - fazę pełnej medykalizacji społecznej, polegającej na definiowaniu zjawisk i problemów społecznych w kategoriach medycznych i poddawaniu ich nadzorowi medycznemu ${ }^{30}$. Pierwsza połowa XX w. to okres, w którym prewencyjne zdrowie publiczne zaczyna zmieniać się $\mathrm{w}$ terapeutyczne ${ }^{31}$. Istota zmiany polegała na tym, że za równie ważne jak prewencyjne działania prozdrowotne nakierowane na sferę organizacyjną życia społecznego uważać zaczęto prewencyjne działania prozdrowotne nakierowane na jednostkę. Inaczej mówiąc, nie tylko prewencja w przestrzeni życia społecznego musi być realizowana permanentnie, ale także prewencja w odniesieniu do jednostki, czyli proces terapeutyczny powinien być realizowany $\mathrm{w}$ sposób nieprzerwany, nie zaś tylko w sytuacji jawnej choroby.

Tę nową postawę wobec problemu podnoszenia poziomu zdrowotności opisał Henry Sigerist (1891-1957), szwajcarski lekarz i historyk medycyny, ale działający głównie w USA i Kanadzie. W swym klasycznym już dziele Civilization and Disease, którego pierwsze wydanie ukazało się w 1943 r., podkreślał, że wprawdzie warunki zdrowotne w rozwiniętych krajach znacznie się poprawiły, co jest oczywiście ko-

${ }^{30}$ Zob. obszerne omówienie procesu medykalizacji społecznej w: P. Conrad, The Medicalization of Society. On the Transformation of Human Conditions into Treatable Disorders, The Johns Hopkins University Press, Baltimore 2007. Zob. także M. Wieczorkowska, Świat jako klinika. Medykalizacja życia $w$ społeczeństwie ryzyka biomedycznego, [w:] M. Gałuszka (red.), Zdrowie i choroba w społeczeństwie ryzyka biomedycznego, Biuro Promocji i Wydawnictw Uniwersytetu Medycznego w Łodzi, Łódź 2008, s. 107-139. O medykalizacji jako przedmiocie badań socjologii zob. M. Wieczorkowska, Medykalizacja społeczeństwa w socjologii amerykańskiej, „Przegląd Socjologiczny” 2012, nr 61(2), s. 31-56.

${ }^{31}$ Następowanie kolejnych faz było oczywiście procesem, nie zaś wyraźnie określonym przejściem, przede wszystkim jednak przebiegał on inaczej w poszczególnych krajach. Na przykład przyjmuje się, że w Wielkiej Brytanii okres prewencyjny zaczął się już około 1870 r., okres terapeutyczny około 1930 r., a za początek nowej, medykalizacyjnej fazy rozwoju zdrowia publicznego uznaje się rok 1930; zob. A. Goraya, G. Scambler, From Old to New Public Health. Role Tensions and Contradictions, „Critical Public Health" 1998, nr 8(2), s. 141-151. 
rzystne, jednak nie powinno to nas satysfakcjonować, ponieważ musimy też być świadomi niepowodzeń i niedociągnięć. O stanie zdrowotności populacji powinniśmy myśleć nie tylko w oparciu jedynie o aktualne wskaźniki, lecz także w odniesieniu do liczb bezwzględnych ${ }^{32}$. Taki punkt widzenia pozwala zrozumieć, że prewencja medyczna w skali społecznej pozostaje dalece nieskuteczna, jeśli nie towarzyszy jej prewencja medyczna w skali jednostki. Właściwa troska o stan zdrowotności musi dotyczyć i społeczności, i jednostek, a wiec permanentnej prewencji w skali społecznej towarzyszyć musi permanentna terapia jednostek. „Nigdy nie powinniśmy mówić, że warunki zdrowotne są dobre, lecz powinniśmy raczej pytać stale samych siebie, czy są one tak dobre, jak mogłyby być"33. Sigerist mówi to w odniesieniu nie tylko do stanu zdrowotności społeczeństwa, lecz także jednostek. Odniesienie do jednostki jest nawet ważniejsze, ponieważ poziom zdrowotności ostatecznie zależny jest od skuteczności działań medycznych. „Ostatecznie o stanie zdrowia decyduje skuteczność usług medycznych. Nauka medyczna jest marnowana, jeśli nie można jej stosować bez ograniczeń. Potrzebujemy systemu usług medycznych, który dociera do każdego, zdrowego i chorego, bogatego i biednego, i nie ma powodu, dla którego mielibyśmy nie być w stanie stworzyć takiego systemu"34. Zasady prewencji medycznej dotyczące jednostki powinny więc odnosić się nie tylko do aktualnie chorych czy do osób z podejrzeniem choroby, lecz także do osób uważających się za zdrowe i nieodczuwających wyraźnych dolegliwości. Można takie podejście rozumieć jako uznanie, że każdy jest albo będzie pacjentem, ale można też przyjąć interpretację mocniejszą, wedle której każdy jest w jakimś stopniu chory, choć nie każdy jest tego świadomy, a więc należy mu to uświadomić i skłonić do regularnego kontrolowania stanu swego zdrowia.

Postulat permanentnej terapii jest bardzo atrakcyjny dla środowiska medycznego w sytuacji, gdy usługi medyczne są płatne lub w ja-

32 „Health conditions have greatly improved in the economically advanced countries and this is very gratifying, but we should never be satisfied with the results achieved. We should always keep the failures and short-comings in mind. (...) We must not think only in terms of rates but also in absolute figures"; H.E. Sigerist, Civilization and Disease, Cornell University Press, Ithaca-New York 1945, s. 237-238.

33 „We must never say that health conditions are good, but must rather ask ourselves constantly whether they are as good as they could be. The answer is decidedly: no"; ibidem, s. 238.

34 „Health conditions, finally are determined by the effectiveness of medical services. Medical science is wasted unless in can be applied without reservation. We need a system of health services that reaches everybody, healthy and sick, rich and poor, and there is no reason why we should not be able to establish such a system"; ibidem, s. 240 (wyróżnienie - M.N.). 
kiejś części zwracane przez zakłady ubezpieczeniowe czy refundowane przez budżet państwa. Dlatego w Stanach Zjednoczonych i w rozwiniętych krajach europejskich pierwsza połowa XX w. to czas intensywnego propagowania jednostkowych zachowań prewencyjnych, obejmujących nie tylko przestrzeganie zaleceń higieny, odżywiania się czy stylu życia, ale także regularne wizyty u lekarza niezależnie od aktualnego subiektywnego odczucia stanu zdrowia. Lekarze zachęcali swoich pacjentów do regularnego kontrolowania organizmu i zalecali jak najszybsze reagowanie na choćby najmniejsze podejrzenia co do możliwości zagrożeń zdrowotnych; mogli przy tym powoływać się na oficjalne stanowisko różnych organizacji medycznych i państwowych instytutów czy urzędów zdrowia publicznego. Jednak takie przekonywanie może być skuteczne pod warunkiem, że jego adresaci żywią autentyczne obawy co do stabilności swego stanu zdrowia; człowiek nieodczuwający pewnego natężenia lęku przed możliwością zachorowania nie będzie skłonny narzucić sobie prozdrowotnego reżimu kontrolnego. Zachęcaniu do stałego kontrolowania stanu zdrowia musi zatem nieodłącznie towarzyszyć stałe pobudzanie lęku przed możliwością choroby. Strategia permanentnej terapii musi więc być zarazem strategią zarządzania lękiem.

Wkraczanie w fazę terapeutyczną rozwoju zdrowia publicznego $\mathrm{w}$ różnych krajach rozpoczynało się w różnym czasie, ponieważ zależne było od czynników natury kulturowej i obyczajowej. Nie da się nawet wskazać jakichś symbolicznych momentów granicznych, gdyż $\mathrm{w}$ oficjalnym przekazie prozdrowotnym propagowanie regularnych kontroli stanu zdrowia nie przybierało form skrajnych. Intensywna perswazja uprawiana była natomiast przez praktykujących lekarzy, a jej natężenie sprawiało, że wytworzyła się, szczególnie w kręgach ludzi zamożniejszych, swoista atmosfera jednostkowej troski o zdrowie, moda na pozostawanie pod stałą opieką „osobistego” lekarza. Nie mogło to znaleźć odbicia w oficjalnych dokumentach czy wydawnictwach medycznych, ale widoczne jest w przekazach literackich. Jednym z najbardziej znanych utworów literackich ukazujących prozdrowotne oblicze tamtych czasów jest komedia Knock ou le Triomphe de la médecine („Knock, czyli triumf medycyny”), której premiera odbyła się w 1923 r. w paryskim Théâtre des Champs-Élysées. Jej autor, francuski pisarz i poeta Jules Romains (1885-1972), w karykaturalnym ujęciu ukazał cele i intencje świata lekarskiego. Sztuka cieszyła się dużym powodzeniem, wystawiana była na scenach wielu krajów, doczekała się ekranizacji filmowych. 
Akcja sztuki rozgrywa się około $1920 \mathrm{r}$. w małym miasteczku francuskim Saint Maurice, w którym tytułowy doktor Knock przejmuje praktykę lekarską po starszym od siebie lekarzu, postanawiając zmienić dotychczasową postawę miejscowej ludności wobec problemu zdrowia ${ }^{35}$. Jego poprzednik przyjmował mieszkańców miasteczka wtedy, gdy się do niego zgłosili, po tym jak zauważyli jakieś niepokojące oznaki w swym organizmie, on zaś chce zasadniczo zmienić ich rozumienie zdrowia. Wedle Knocka nie ma ludzi zdrowych - każdy jest w jakimś stopniu chory, choć nie każdy zdaje sobie z tego sprawę. Dlatego należy to każdemu uświadomić i skłonić, by kontrolował swój stan zdrowia, nie tylko regularnie odwiedzając lekarza, ale także wyrabiając w sobie trwały nawyk właściwego trybu życia. Doktor Knock tak wyraża swoje rozumienie prewencji medycznej:

Dajecie mi kanton zaludniony kilkoma tysiącami jednostek szarych, zwykłych, nieokreślonych. Moją rolą jest określić ich, sprowadzić ich do istnienia medycznego. Kładę ich do łóżek i patrzę, co z tego może wyniknąć: gruźlik, neurotyk, chory na arteriosklerozę, cokolwiek, ale przecież ktoś, dobry Boże, ktoś! Nic mnie tak nie irytuje, jak taka istota, ni pies, ni wydra, którą nazywa się człowiekiem zdrowym ${ }^{36}$.

Stosując rozmaite formy i metody perswazji, zachęty, posługując się odpowiednio dobranym słownictwem, Knock sugestywnie ukazuje zagrożenia zdrowotne, na które narażeni są wszyscy, którzy nie przestrzegają stałych zasad permanentnej terapii. Udaje mu się zmienić beztroskie podejście do stanu własnej zdrowotności na utrwaloną samoświadomość znajdowania się w stanie choroby, której towarzyszy przekonanie, że stan ten można minimalizować, a przynajmniej nie dopuszczać do jego pogarszania się, dzięki właściwej postawie prozdrowotnej. Doktor Knock doprowadza do pełnej medykalizacji miasteczka - mieszkańcy podporządkowują się całkowicie ustalonym przez niego zasadom ochrony zdrowia i stosują je w życiu codziennym, poczynając od regularnego mierzenia temperatury ciała, a na prewencyjnym zażywaniu medykamentów kończąc.

Knock oczywiście zapewnia sobie dzięki temu stałe, wysokie dochody, jak też zarazem zwiększa dochody miejscowego aptekarza czy

${ }^{35}$ Omówienie problematyki utworu podajemy za: I. Bamforth, Knock. A Study in Medical Cynicism, „Medical Humanities” 2002, nr 28(1), s. 14-18.

${ }^{36}$ Cyt. za: M. Kita, Syndrom Knocka, czyli czego językoznawca może się dowiedzieć, badajac teksty wywiadów, [w:] M. Kita, J. Grzenia (red.), Porozmawiajmy o rozmowie. Lingwistyczne aspekty dialogu, Wydawnictwo Uniwersytetu Śląskiego, Katowice 2003, s. 159. 
innych osób świadczących usługi związane z opieką zdrowotną, jednak nie stanowi to głównego celu jego postępowania. Knock jest mesjaszem zdrowia, jego misją jest przemiana społeczeństwa w zbiorowość jednostek, dla których zdrowie staje się wartością najwyższą, a stała troska o nie moralnym obowiązkiem. Kiedy miejscowy farmaceuta powiada, że ludzie muszą najpierw zachorować, a dopiero po tym można ich leczyć, Knock odpowiada, że jest to pogląd fałszywy, nadto zaś szkodliwy, ponieważ utwierdza ludzi w błędnym przekonaniu, że są zdrowi. Nikt nie jest zdrowy, ponieważ niebezpieczeństwo choroby czai się zarówno na zewnątrz, jak i wewnątrz człowieka. W pewnym momencie Knock mówi, że czynniki zagrażające zdrowiu są wszędzie, jak roztocze kurzu domowego; takie stanowisko jest podstawą realizacji strategii zarządzania lękiem ${ }^{37}$. Knock jest mistrzem w sztuce wzmacniania tej szczególnej formy lęku, jakim jest obawa przed pogorszeniem stanu zdrowia, dlatego udaje mu się stworzyć mały świat, w pełni podporządkowany medycynie, w którym wszystko, co nie pozostaje w zgodności ze zmedykalizowaną świadomością mieszkańców, jest tłumione lub odrzucane ${ }^{38}$.

Można by uznać, że komediowy obraz małej społeczności podporządkowanej całkowicie reżimowi medycznemu jest tylko fikcją literacką przedstawiającą wyolbrzymione karykaturalnie tendencje lub wadliwości rzeczywiście obecne w środowisku lekarskim. Jednak byłaby to błędna interpretacja - Jules Romains jedynie komediowo przejaskrawił zjawisko realnie rozwijające się wówczas w sferze zdrowia publicznego. Od początku XX w. w wielu krajach, także we Francji, czynniki oficjalne usilnie zalecały przestrzeganie zasad higieny i stosowanie się do zaleceń medycyny, uzasadniając to odkryciami z zakresu przede wszystkim bakteriologii. Ta propaganda prozdrowotna szczególnie we Francji padała na podatny grunt, ponieważ podstawy bakteriologii stworzył francuski uczony Ludwik Pasteur (1822-1895), co wzmacniało poczucie dumy narodowej Francuzów i ułatwiało ak-

${ }^{37}$ Por. I. Bamford, Knock. A Study in Medical..., op. cit., „Once Knock has made it explicit, danger is like the house-dust mite: everywhere. One might call it «Getting the Fear»"; ibidem, s. 15.

38 ,Whatever fails to fit this world-as-interpreted-by medicine is suppressed or rejected: medicine for the inhabitants of Saint Maurice becomes the very content of their lives. (...) He leans on what he is expert at inducing - fear: a contrived dart of panic among the cast that can make laughter from the auditorium sound oddly complicit or uneasy. The inhabitants of St Maurice might be suffering from maladies imaginaires, but Knock is a master at the art of reinforcing that particular form of fright. His strategy is simple but effective: he defines the bad, and dictates the good"; ibidem, s. 16. 
ceptację argumentacji ${ }^{39}$. Działano faktycznie w zgodzie z ideologią medycyny prewencyjnej, której tak wyrazistym przedstawicielem był Milton J. Rosenau; co więcej, podstawę realizacji tej ideologii stanowiła $\mathrm{w}$ istocie postulowana przez Rosenaua strategia zarządzania lękiem. Amerykański epidemiolog nie rozważał problemu, jakie mogą być konsekwencje świadomego podtrzymywania lęku jako metody wdrażania do zachowań prozdrowotnych. Francuski dramaturg przedstawił te konsekwencje w przejaskrawionej i skarykaturyzowanej formie, co jednak nie umniejsza trafności jego intuicji.

Przy tych rozważaniach nie możemy zapominać o fakcie, że w dużej mierze to dzięki prowadzonej w ramach zdrowia publicznego usilnej propagandzie zachowań prozdrowotnych tak znacząco podniósł się poziom zdrowotności, długości życia i jego jakości. Nikt rozsądny nie będzie kwestionował tego faktu czy odrzucał tezy, że troska o własne zdrowie jest powinnością każdej osoby zarówno ze względu na nią samą, jak z uwagi na inne osoby. Należy jednak postawić pytanie, czy da się nakreślić ramy, w jakich władza państwowa ma prawo wymuszać na jednostce spełnianie tych obowiązków, i do jakiego stopnia może je wymuszać. Za datę symboliczną, kończącą terapeutyczną i rozpoczynającą medykalizacyjną fazę rozwoju zdrowia publicznego, można uznać rok 1946. W tym roku umiera Milton J. Rosenau, lekarz i uczony mogący uchodzić za najbardziej znaczącego wyraziciela fazy prewencyjnej i fazy terapeutycznej rozwoju zdrowia publicznego. Ale w tym samym roku Światowa Organizacja Zdrowia (WHO) ogłasza swoją Konstytucję, w której nie tylko wskazuje swoje cele, zadania i metody ich realizacji, ale także wyznacza kierunek, w jakim ma podążać zdrowie publiczne.

W dniach od 19 czerwca do 22 lipca 1946 r. w Nowym Jorku miała miejsce International Health Conference; w ostatnim dniu Konferencji przyjęto Konstytucję WHO, którą podpisało 61 państw. Z punktu widzenia niniejszych rozważań istotna jest, zamieszczona już na samym początku Konstytucji WHO, nowa definicja zdrowia. W odróżnieniu od dotychczasowego określania zdrowia w sposób negatywny - jako braku choroby - zdefiniowano zdrowie w sposób pozytywny. „Zdrowie

${ }^{39}$ Cytowany powyżej autor powołuje się na biografa słynnej filozofki francuskiej, którego świadectwo warto przytoczyć. „Te kampanie przeciwko niewidzialnemu zagrożeniu pośród francuskiej populacji niewątpliwie odniosły skutek, jak można przypuszczać na podstawie zwyczajów niewątpliwie inteligentnej rodziny z klasy średniej z tego okresu: biograf Simone Weil donosi, że cała jej rodzina w pierwszej dekadzie XX w. żyła w strachu przed drobnoustrojami, obsesyjnie myto ręce, otwierano drzwi łokciami i generalnie unikano kontaktu fizycznego"; ibidem, s. 16. 
jest całkowitym dobrostanem fizycznym, psychicznym i społecznym, a nie tylko brakiem choroby lub ułomności" ${ }^{40}$. Jest rzeczą oczywistą, że przy takim rozumieniu zdrowia nikt nie jest zdrowy, ponieważ nikt nie może cieszyć się pełnym dobrostanem fizycznym, psychicznym i społecznym, chyba że w krótkich odcinkach czasowych. Jeśli spojrzeć $\mathrm{z}$ innego punktu widzenia, można uznać, że zgodnie $\mathrm{z}$ tą definicją każdy jest chory. Można oczywiście domniemywać, że zgodnie z intencjami autorów definicji zdrowie zostaje pojęte nie jako określony stan faktyczny, lecz jako ideał, do którego należy nieustannie dążyć. $\mathrm{Na}$ czym jednak miałoby polegać dążenie do takiego ideału, jeśli nie na permanentnej prewencji i permanentnej terapii? Przecież nigdy nie będziemy tak zabezpieczeni przed chorobami, żeby nie można było zwiększać zabezpieczenia, i nigdy nie będziemy tak zdrowi, abyśmy nie mogli stawać się zdrowsi. Tym samym jednak u podstaw nowej definicji zdrowia leży postulat wprowadzenia pełnej medykalizacji społecznej. Warunkiem medykalizowania społeczeństwa jest natomiast stałe utrzymywanie się $\mathrm{w}$ nim pewnego poziomu lęku przed zachorowaniem, a jeśli ten lęk obniża się w stopniu utrudniającym postępy medykalizacji, należy go pobudzać. Polityka prozdrowotna opiera się $\mathrm{w}$ istocie na realizowaniu strategii zarządzania lękiem, tak jak to postulował Milton J. Rosenau, a czego intuicyjnie obawiał się Jules Romains.

Granica między „oświeconą” oceną niebezpieczeństwa a stałym lękiem przed zachorowaniem nie jest wyraźna i jednoznacznie określona, stąd w postępującym we współczesnych społeczeństwach procesie zwiększania się medykalizacji może dochodzić, i faktycznie dochodzi, do różnego rodzaju błędów i nadużyć. Postulując podtrzymywanie jakiegoś minimalnego poziomu lęku, Rosenau nie zastanowił się, czy w ogóle jest możliwe, aby poziom lęku pozostawał mniej więcej stały, czy raczej w kontekście zwiększającego się poczucia bezpieczeństwa zdrowotnego będącego skutkiem rozwoju medycyny konieczne staje się stałe podtrzymywanie lęku przez wskazywanie na coraz to nowe zagrożenia naszej zdrowotności. Romains to właśnie przeczuwał i w swojej komedii ukazał niebezpieczeństwo zachwiania proporcji między terapeutycznymi a prewencyjnymi działaniami medycyny. Człowiek idzie do lekarza dlatego, że jest chory, czyli w celach terapeutycznych, lub dlatego, że nie chce zachorować, czyli w celach

40 „Health is a state of complete physical, mental, and social well-being and not merely the absence of disease or infirmity"; Constitution of the WHO, http://www.who. int/governance/eb/who_constitution_en.pdf [dostęp: 23.04.2021]. 
prewencyjnych. Niewłaściwa forma dominacji działań zapobiegawczych nad działaniami leczniczymi jest konsekwencją utrzymywania wysokiego poziomu lęku przez perswazyjną argumentację, iż człowiek chodzi do lekarza nie dlatego, że jest chory, i nie dlatego, że chce skontrolować stan organizmu, lecz dlatego, że nie może być zdrowy ${ }^{41}$. Postulowany przez Rosenaua proces racjonalnego oceniania zagrożeń dla zdrowia przekształca się w stałe podtrzymywanie lęku przed nimi. A człowiek żyjący w stałym lęku podatny jest na perswazję i łatwo nim kierować. Zdrowie publiczne może w swym rozwoju zejść z drogi służenia człowiekowi i społeczeństwu, wkraczając na drogę służenia interesom świata medycznego i związanego z nim świata polityki.

\section{Bibliografia}

Bamforth I., Knock. A Study in Medical Cynicism, „Medical Humanities" 2002, nr 28(1).

Conrad P., The Medicalization of Society. On the Transformation of Human Conditions into Treatable Disorders, The Johns Hopkins University Press, Baltimore 2007.

Constitution of the WHO, http://www.who.int/governance/eb/who_ constitution_en.pdf.

Felton L.D., Milton Joseph Rosenau, „Journal of Bacteriology” 1947, nr 53(1).

Goraya A., Scambler G., From Old to New Public Health. Role Tensions and Contradictions, „Critical Public Health” 1998, nr 8(2).

Kita M., Syndrom Knocka, czyli czego językoznawca może się dowiedzieć, badajac teksty wywiadów, [w:] M. Kita, J. Grzenia (red.), Porozmawiajmy o rozmowie. Lingwistyczne aspekty dialogu, Wydawnictwo Uniwersytetu Śląskiego, Katowice 2003.

Lorenz M., Proto-eugenic Thought and Breeding Utopias in the United States before 1870, „Bulletin of the German Historical Institute”, fall 2008, $\mathrm{nr} 43$.

Markfield M.H., A More Perfect Union: Eugenics in America, „National Academy of Elder Law Attorneys Journal”, spring 2019, vol. 15.

${ }^{41}$ „Despite all our best efforts illness refuses to disappear. It takes on new forms; it turns up where nobody left it; it gets invented by the political and social relations of civilisation itself, which includes the medical profession. Then the misfortunes to which doctors owe their livelihood - illness is, at least, a natural evil - become morally ambiguous. People start to visit the doctor not so much because they are ill, but because they can't be healthy"; I. Bamford, Knock. A Study in Medical..., op. cit., s. 17. 
Milton J. Rosenau (1869-1946) i strategia zarządzania lękiem...

Maxcy K.F. (red.), Rosenau's Preventive Medicine and Public Health, Appleton-Century-Crofts, New York 1956.

McKinley J.B., McKinley S.M., Beaglehole R., Trends in Death and Disease and the Contribution of Medical Measures, [w:] H. E. Freeman, S. Levine (red.), Handbook of Medical Sociology, Prentice Hall, Englewood Cliffs, N. J. 1988.

Milton J. Rosenau, Biogram w Wikipedii: https://en.wikipedia.org/ wiki/Milton_J._Rosenau.

Milton Joseph Rosenau, „Canadian Journal of Public Health / Revue Canadienne de Santé Publique” 1946, nr 37(8).

Nowacka M., Od policji medycznej do zdrowia publicznego. Rozwój administracji zdrowotnej w XIX wieku, w druku.

Nowacka M., Kopania J., Od medycyny prewencyjnej do programów eugenicznych. Droga rozwojowa zdrowia publicznego, „Kwartalnik Filozoficzny" 2016, XLIV, nr 1.

Riddle O., Biographical Memoir of Charles Benedict Davenport 18661944, „National Academy of Sciences of the United States of America. Biographical Memoirs" 1947, vol. XXV, fourth memoir.

Rogers F.B., Fifty Years of Rosenau's Textbook (1913-1963), „American Journal of Public Health" 1963, nr 53(8).

Rosenau M.J., Disinfection and Disinfectants. A Practical Guide for Sanitariants, Health and Quarantine Officers, P. Blakiston's Son \& Co, Philadelphia 1902.

Rosenau M.J., The Uses Of Fear In Preventive Medicine, „Boston Medical and Surgical Journal” 1910, nr 162(10).

Rosenau M.J., The Milk Question, Houghton Mifflin Company, Boston-New York 1912.

Rosenau M.J., Preventive Medicine and Hygiene, D. Appleton and Company, New York-London 1913.

Rosenau M.J., All About Milk, Metropolitan Life Insurance Company, New York 1919.

Rosenberg Ch.E., Charles Benedict Davenport and the Beginning of Human Genetics, „Bulletin of the History of Medicine” 1961, nr 35(3).

Sigerist H.E., Civilization and Disease, Cornell University Press, Ithaca-New York 1945.

The Future of Public Health, Committee for the Study of the Future of Public Health; Division of Health Care Services, National Academy Press, Washington 1988. 
Wieczorkowska M., Świat jako klinika. Medykalizacja życia w społeczeństwie ryzyka biomedycznego, [w:] M. Gałuszka (red.), Zdrowie $i$ choroba $w$ społeczeństwie ryzyka biomedycznego, Biuro Promocji i Wydawnictw Uniwersytetu Medycznego w Łodzi, Łódź 2008.

Wieczorkowska M., Medykalizacja społeczeństwa w socjologii amerykańskiej, „Przegląd Socjologiczny” 2012, nr 61(2).

Winslow Ch.-E.A., The Conquest of Epidemic Disease. A Chapter in the History of Ideas, The University of Wisconsin Press, Wisconsin 1980. 